\title{
Single nanomolar doxorubicin exposure triggers compensatory mitochondrial responses in H9c2 cardiomyoblasts
}

\author{
Luciana L. Ferreira ${ }^{a}$, Teresa Cunha-Oliveira ${ }^{a}$, Caroline D. Veloso ${ }^{a}$, Cláudio F. Costa ${ }^{a}$, \\ Kendall B. Wallace ${ }^{\mathrm{b}}$, Paulo J. Oliveira, ${ }^{\mathrm{a}, *}$ \\ ${ }^{\text {a }}$ CNC - Center for Neuroscience and Cell Biology, University of Coimbra, UC Biotech Building, Biocant Park, 3060-197, Cantanhede, Portugal \\ ${ }^{\mathrm{b}}$ Department of Biomedical Sciences, University of Minnesota Medical School, Duluth, MN, 55812, USA
}

\section{A R T I C L E I N F O}

\section{Keywords:}

Doxorubicin

H9c2 cells

Cardiotoxicity

Mitochondria

DNA methylation

\begin{abstract}
A B S T R A C T
Dose-dependent and cumulative cardiotoxicity associated with doxorubicin (DOX) is the main limitation of anticancer therapy. Pediatric cancer survivors are particularly vulnerable, and no effective prevention measures are available. The aim of the present study was to investigate the persistent effects of nanomolar DOX concentrations and determine whether a pretreatment would induce mitochondrial adaptations in H9c2 cardiomyoblasts. H9c2 cells were incubated with DOX (10 and $25 \mathrm{nM})$ for $24 \mathrm{~h}$, followed by 9 days of recovery in drugfree medium. We found that the sub-therapeutic DOX treatment induced persistent hypertrophy and dose-dependent cell cycle arrest in G2/M. Glycolytic activity, indirectly based on extracellular acidification rate, and basal respiration were significantly decreased in DOX-treated cells compared to controls, although both groups showed similar maximal respiration. Additionally, nanomolar DOX pretreatment resulted in upregulation of mitochondrial DNA transcripts accompanied by a decrease in DNA methyltransferase 1 (DNMT1) and global methylation levels. Finally, the pretreatment with DOX ameliorated H9c2 cells resistance against a subsequent exposure to DOX. These results suggest that nanomolar DOX pretreatment induced a beneficial and possibly epigenetic-based mitochondrial adaptation, raising the possibility that an early sub-therapeutic DOX treatment can be used as a preconditioning and protective approach during anticancer therapies.
\end{abstract}

\section{Introduction}

Doxorubicin (DOX) is an anthracycline and one of the most effective and frequently used drugs prescribed for the treatment of cancer. DOX has shown efficacy against solid tumors, leukemias and lymphomas, including Hodgkin's lymphoma, bladder, breast and thyroid cancers, multiple myeloma and others (Bonadonna et al., 1969, 1970). DNA intercalation (Coldwell et al., 2008; Yang et al., 2014) and topoisomerase II $\alpha$ (TOPII $\alpha$ ) inhibition (Nitiss, 2009) are the most widely accepted mechanisms for DOX antineoplastic activity. However, the clinical use of DOX is limited by its dose-dependent and cumulative cardiotoxicity (Von Hoff et al., 1979), mostly expressed as cardiomyopathy and congestive heart failure (Minotti et al., 2004). Delayed onset manifestation of DOX-toxicity is a major concern, especially in pediatric patients (Goorin et al., 1990; Lipshultz et al., 1991). This manifestation can appear many years after the completion of the therapy and was first described in the 1990's (Goorin et al., 1990; Lipshultz et al., 1991). The most employed strategy to prevent DOX-induced cardiotoxicity is the limitation of cumulative DOX doses, which may translate into lower cancer response rates (Wouters et al., 2005).

Pathophysiologically, a panoply of mechanisms underlies DOXcardiotoxicity, making the identification of clear prevention or treatment strategies difficult. However, the over-production of reactive oxygen species (ROS), generated predominantly in cardiac mitochondria, is considered the primary initiating event in the cascade of intracellular modifications. In mitochondria, DOX is mostly reduced by NADH dehydrogenase and undergoes redox cycling, generating ROS in the process (Doroshow and Davies, 1986). The excessive generation of ROS causes damage to many cellular structures, and mitochondrial dysfunction is considered a hallmark of DOX-induced cardiotoxicity (Berthiaume and Wallace, 2007a; Serrano et al., 1999; Zhou et al., 2001a). Besides lipid peroxidation and DNA oxidation, defects on respiratory chain/oxidative phosphorylation, decreased production of ATP, unbalanced cellular calcium homeostasis, and a metabolic switch

\footnotetext{
${ }^{*}$ Corresponding author. MitoXT (Mitochondrial Toxicology and Experimental Therapeutics Laboratory), CNC - Center for Neuroscience and Cell Biology, University of Coimbra, UC Biotech Building (Lote 8A), Biocant Park, 3060-197, Cantanhede, Portugal.

E-mail addresses: luciana.cl.ferreira@gmail.com (L.L. Ferreira), teresa.oliveira@uc-biotech.pt (T. Cunha-Oliveira), velosocaroline@gmail.com (C.D. Veloso), claudio.costa@uc-biotech.pt (C.F. Costa), kwallace@d.umn.edu (K.B. Wallace), pauloliv@cnc.uc.pt (P.J. Oliveira).
} 
were also observed and suggested to act synergistically in cellular dysfunction (Ascensao et al., 2011; Carvalho et al., 2010; Lv et al., 2012; Wallace, 2007). In addition, DOX not only has a high affinity for nuclear DNA, leading to inhibition of nucleic acid synthesis and transcription, but also promotes the formation of protein-linked DNA double strand breaks by forming a ternary TOPII $\beta$-DOX-DNA complex (Zhang et al., 2012). In contrast to TOPII $\alpha$ that is mostly present in proliferating cells, TOPII $\beta$ is found predominantly in non-proliferating cells, such as adult cardiomyocytes (Capranico et al., 1992). In cultured cells, DOX treatments induced morphological alterations including breakage of the mitochondrial network or increase of nuclear area, along with increased p53-induced apoptosis and mitochondrial depolarization (Sardao et al., 2009a, b). The toxic effects of DOX have also been extensively studied in various animal models (Desai et al., 2013; Niu et al., 2009; Oliveira et al., 2004; Pereira et al., 2012; Zhou et al., 2001b; Zhu et al., 2008). DOX exposure was also associated with persistent alterations of gene expression (Berthiaume and Wallace, 2007b) and severe defects on functionally competent cardiac progenitor cells (CPC) (De Angelis et al., 2010; Huang et al., 2010). CPC are particularly susceptible to DOX, which is a critical factor for neovascularization and sustainability of functional resiliency in cardiac tissue (De Angelis et al., 2010). This capacity for cardiac regeneration is especially important during the first years of life, since regenerative potential has been described to decrease with age.

Adaptive responses have been investigated in the context of cell toxicology. This phenomenon is based on the notion that low doses of toxic agents stimulate adaptive mechanisms, resulting in less adverse effects after a subsequent larger exposure. It has been previously shown that DOX treatment in vivo causes adaptive responsive that include reprogramming of metabolic flux from glycolysis to fatty acid oxidation (Carvalho et al., 2010). Our hypothesis is that nanomolar concentrations of DOX confer H9c2 cells protection against a second DOX treatment at higher doses, due to a mitochondrial adaptive-like effect. Therefore, the relevance of the results is that pretreatment with low, sub-clinical doses of DOX may induce a cardiac adaptive response, thereby improving the overall success of DOX-based chemotherapies, by decreasing cardiotoxicity events.

\section{Material and methods}

\subsection{Cell culture}

H9c2 cells are a particularly popular rat heart-derived cell line, frequently used as a model of cardiac myocytes (Kimes and Brandt, 1976). However, unlike cardiomyocytes, H9c2 are proliferating cells and possess some features of skeletal muscle (Kimes and Brandt, 1976; Lenco et al., 2015), resembling immature myogenic cells or, ultimately, undifferentiated cardiac cells. H9c2(2-1), a subclone of the original clonal cell line H9c2, was purchased from American Type Culture Collection (ATCC $\left.{ }^{\circ} \mathrm{CRL}\right\urcorner 1446^{\mathrm{TM}}$ ). Cells were cultured in $25 \mathrm{mM}$ glucose Dulbecco's modified Eagle's medium (DMEM D5648, Sigma) supplemented with $1.5 \mathrm{~g} / \mathrm{l}$ of sodium bicarbonate (S6014, Sigma), antibiotic/ antimycotic solution (15240-062, Gibco) and 10\% fetal bovine serum (FBS; 10270-106, Gibco). The cell culture was maintained at $37^{\circ} \mathrm{C}$ in a humidified atmosphere of $5 \% \mathrm{CO}_{2}$. $\mathrm{H} 9 \mathrm{c} 2$ cells were passaged when cells reached approximately $80 \%$ of confluence and the medium was changed every 2-3 days. Cells were used between passage 6 and 20 .

\subsection{Cell treatments and experimental design}

The experimental design is shown in Figs. 1A and 6A. DOX (D1515, Sigma) was prepared freshly in water at a $10 \mathrm{mM}$ stock concentration; intermediary dilutions of this working stock were also made in water. If not indicated otherwise, cells were seeded at a density of $1.8 \times 10^{3}$ cells $/ \mathrm{cm}^{2}$. One day post-seeding, H9c2 cells were exposed to DOX (10-25 nM) for $24 \mathrm{~h}$, after which the cells were rinsed with phosphate buffered saline solution (PBS) and the culture medium replaced. After three days of recovery, H9c2 cells were passaged (CTR $1: 3$, DOX-treated cells $1: 2$ ), and this step was repeated again at day 6 (starting from the recovery time). In total, four time-points were established for the pre-exposure period; days 0, 3, 6, and 9 (Fig. 1A). For the second exposure (Fig. 6A), H9c2 cells were re-seeded on day 9 at a density of $6.0 \times 10^{3}$ cells $/ \mathrm{cm}^{2} ; 24 \mathrm{~h}$ later they were incubated with $\operatorname{DOX}(0.2,0.5$ and $1 \mu \mathrm{M})$ or iodoacetate $(2 \mu \mathrm{M})$, an irreversible inhibitor of glyceraldehyde-3-phosphate dehydrogenase (GAPDH) for further $24 \mathrm{~h}$. DOX concentrations were chosen based on human plasma kinetics studies which reported initial peak plasma concentrations of $0.2-5 \mu \mathrm{M}$ that further decline to nanomolar concentrations within $1 \mathrm{~h}$ (Greene et al., 1983).

\subsection{Cell mass measurements}

Cell mass was measured by the sulforhodamine B (SRB) assay (Vichai and Kirtikara, 2006). Briefly, cells were seeded at $6.0 \times 10^{3}$ cells $/ \mathrm{cm}^{2}$ in 48 well-plates at a final volume of $500 \mu \mathrm{l}$ per well. At the respective time-points the medium was removed, the wells rinsed with PBS and the cells fixed overnight with ice-cold acetic acid/ methanol $(1 \% \mathrm{v} / \mathrm{v})$ at $-20^{\circ} \mathrm{C}$. Following fixation, plates were dried and incubated with $200 \mu \mathrm{l}$ of SRB $0.05 \%$ (w/v) (S9012, Sigma) in 1\% acetic acid for $1 \mathrm{~h}$ at $37^{\circ} \mathrm{C}$. The unbound dye was then removed by washing the wells with $1 \%$ acetic acid and the plates were dried again. Finally, $1 \mathrm{ml}$ of Tris ( $10 \mathrm{mM}, \mathrm{pH} 10$ ) was added to the plates to dissolve SRB and optical density was read at $530 \mathrm{~nm}$.

\subsection{Metabolic cell viability determination using resazurin assay}

The resazurin assay is based on the ability of viable cells to reduce resazurin into resorufin, whose fluorescence is then indicative of the cellular redox activity. Cells were seeded at a density of $6.0 \times 10^{3}$ cells/ $\mathrm{cm}^{2}$ in 96-well plates. The working resazurin solution was prepared in cell culture medium immediately prior the assay, at a concentration of $10 \mu \mathrm{g} / \mathrm{ml}$ (R7017, Sigma). At the proper time-point, cell medium was removed from the plate and $80 \mu$ of resazurin solution was added in each well and incubated for $90 \mathrm{~min}$ at $37^{\circ} \mathrm{C}$ in a humidified atmosphere of $5 \% \mathrm{CO}_{2}$. Each independent replicate had four technical replicates in the same plate. Fluorescence was measured using the excitation wavelength of $540 \mathrm{~nm}$ and emission of $590 \mathrm{~nm}$.

\subsection{Mitochondrial transmembrane electric potential measurements}

Tetramethylrhodamine ethyl ester perchlorate $\left(\mathrm{TMRE}^{+}\right.$) is a cationic, lipophilic fluorescent dye that accumulates in the negatively charged mitochondrial matrix and can be used to assess changes in mitochondrial transmembrane potential $\left(\Delta \Psi_{\mathrm{m}}\right)$ (Brand and Nicholls, 2011). TMRE ${ }^{+}$(115532-52-0, Santa Cruz) stock was prepared at a concentration of $10 \mathrm{mg} / \mathrm{ml}$ in DMSO and stored at $-20^{\circ} \mathrm{C}$. Working stocks of $50 \mu \mathrm{M}$ were also made by dilution in DMSO. H9c2 cells were seeded in 96-well plates at a density of $6.0 \times 10^{3} \mathrm{cells} / \mathrm{cm}^{2}$ in a final volume of $200 \mu$ l. Each sample had at least six technical replicates in the same plate. At the proper time-point the wells were washed with PBS and incubated in the dark for $1 \mathrm{~h}$ at $37^{\circ} \mathrm{C}$ with $100 \mu \mathrm{l}$ of basal medium (109.5 mM NaCl, $5.4 \mathrm{mM} \mathrm{KCl}, 1.8 \mathrm{mM} \mathrm{CaCl}_{2}, 0.91 \mathrm{mM} \mathrm{NaH}_{2} \mathrm{PO}_{4}, 1 \mathrm{mM}$ $\mathrm{MgCl}_{2}, 25 \mathrm{mM}$ glucose, $25 \mathrm{mM}$ Hepes, $\mathrm{pH}$ 7.4) supplemented with $300 \mathrm{nM}$ of $\mathrm{TMRE}^{+}$. The basal $\mathrm{TMRE}^{+}$fluorescence intensity was measured during $15 \mathrm{~min}$ in a plate reader with $549 \mathrm{~nm}$ excitation and $575 \mathrm{~nm}$ emission. Oligomycin and FCCP (final concentration of $2 \mu \mathrm{g} / \mathrm{ml}$ and $2.5 \mu \mathrm{M}$, respectively) were added to the wells to dissipate $\Delta \Psi_{\mathrm{m}}$ and unquench $\mathrm{TMRE}^{+}$from mitochondria, and a kinetic curve for fluorescence was generated for $10 \mathrm{~min}$ with $1 \mathrm{~min}$ intervals. Finally, Hoechst 33342 ( $1 \mu \mathrm{g} / \mathrm{ml}$; B2261, Sigma) was added to the medium and after $5 \mathrm{~min}$ the fluorescence was measured at an excitation wavelength of $355 \mathrm{~nm}$ and an emission of $465 \mathrm{~nm}$. The results were calculated by the 
difference between the maximum and the baseline values of $\mathrm{TMRE}^{+}$in quenching mode and normalized by Hoechst intensity.

\subsection{Live epifluorescence microscopy}

For epifluorescence microscopy, cells were seeded in 6 well-plates with a glass coverslip in each well, at a density of $2.2 \times 10^{3}$ cells $/ \mathrm{cm}^{2}$ in a final volume of $2 \mathrm{ml}$ per well. At the proper time-points, cells were washed with PBS and incubated with the fluorescent probes for $30 \mathrm{~min}$, at $37^{\circ} \mathrm{C}$ in the dark. TMRE ${ }^{+}(50 \mathrm{nM} ; 115532-52-0$, Santa Cruz) and Hoechst $33342(0.75 \mu \mathrm{g} / \mathrm{ml}$; B2261, Sigma) were added in microscopy

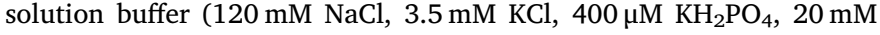
Hepes, $5 \mathrm{mM} \mathrm{NaHCO}_{3}, 1.2 \mathrm{mM} \mathrm{Na}_{2} \mathrm{SO}_{4}, 15 \mathrm{mM}$ glucose, $\mathrm{pH}$ 7.4) supplemented with $1.2 \mathrm{mM}$ and $1.3 \mathrm{mM}$ of $\mathrm{MgCl}_{2}$ and $\mathrm{CaCl}_{2}$, respectively. Images were obtained using a Nikon eclipse Ti-S fluorescence microscope and processed using the software ImageJ $1.49 \mathrm{v}$. Individual cellular and nuclear areas were also measured with ImageJ.

\subsection{Cell cycle analysis}

$\mathrm{H} 9 \mathrm{c} 2$ cells were trypsinized, centrifuged at $250 \times \mathrm{g}$ for $3 \mathrm{~min}$, washed with PBS and fixed overnight by adding 70\% ice-cold ethanol $\left(-20^{\circ} \mathrm{C}\right)$. Cells were then centrifuged at $400 \times g$ at room temperature (RT) and ethanol was discarded. Cells were washed with filtered PBS and, after a second centrifugation, re-suspended in $500 \mu \mathrm{l}$ of a PBS/ EDTA $2 \mathrm{mM}$ /Tween $0.1 \%$ solution supplemented with RNase $(20 \mu \mathrm{g} /$ $\mathrm{ml}$; 12091-021, Invitrogen). The samples were left at RT for $30 \mathrm{~min}$. Finally, propidium iodide (P3566, Molecular Probes) was added to the solution at a final concentration of $20 \mu \mathrm{g} / \mathrm{ml}$ and incubated for $30 \mathrm{~min}$ at $37^{\circ} \mathrm{C}$. The DNA content was analyzed following 20,000 events per sample by using an Accuri ${ }^{\mathrm{TM}}$ C6 flow cytometer (Becton Dickinson). The percentage of cells in G1/G0, S and G2/M was determined using FlowJo V10 software (Ashland, OR, USA).

\subsection{Mitochondrial oxygen consumption rates}

Mitochondrial profile provided by Seahorse XF Cell Mito Stress Test (OCR: oxygen consumption rate) and glycolysis rate based on the XF Glycolysis Stress Test (ECAR: extracellular acidification rate) were determined using a Seahorse $\mathrm{XF}^{\mathrm{e}} 96$ analyzer (Agilent Technologies, Santa Clara, CA). H9c2 cells were seeded on $\mathrm{XF}^{\mathrm{e}} 96$ cell culture plates $\left(1.5 \times 10^{4}\right.$ cells $/ 80 \mu \mathrm{L} /$ well $)$ in triplicate and cultured for $24 \mathrm{~h}$ at $37^{\circ} \mathrm{C}$ in a humidified incubator with $5 \% \mathrm{CO}_{2}$. One hour prior to the assay the plate was rinsed twice with PBS and $175 \mu$ of the appropriate serumfree assay medium with adjusted $\mathrm{pH}$ to 7.4 was added (DMEM SigmaAldrich D5030 supplemented with $25 \mathrm{mM}$ of glucose and $4 \mathrm{mM}$ of glutamine, or DMEM D5030 supplemented only with $4 \mathrm{mM}$ of glutamine for OCR and ECAR measurements, respectively) and the plate was incubated at $37^{\circ} \mathrm{C}$ without $\mathrm{CO}_{2}$. A constant volume of $25 \mu \mathrm{l}$ of the compounds was pre-loaded into the respective ports of the cartridges. For OCR measurements, the sequential addition and the respective final concentration was: $1 \mu \mathrm{M}$ of oligomycin (Port A), $1 \mu \mathrm{M}$ of FCCP (Port B), $1 \mu \mathrm{M}$ of rotenone and $1 \mu \mathrm{M}$ of antimycin (Port C). For ECAR the sequence was: $10 \mathrm{mM}$ of glucose (Port A), $1 \mu \mathrm{M}$ of oligomycin (Port B) and $50 \mathrm{mM}$ of 2-deoxyglucose (2-DG; Port C). OCR and ECAR values were normalized by cell mass, determined by the SRB assay, and analyzed using Wave v2.3 software (Agilent Technologies, Santa Clara, CA).

\subsection{Adenine nucleotide measurement (ATP/ADP/AMP)}

ATP, ADP and AMP levels were measured by HPLC. All steps were carried out on ice or at $4{ }^{\circ} \mathrm{C}$. For the nucleotides extraction, cells were rinsed with PBS, followed by the addition of $500 \mu \mathrm{l}$ ice-cold $0.6 \mathrm{M}$ $\mathrm{HClO}_{4}$ to each dish. The dishes were scraped and the lysates were centrifuged for $10 \mathrm{~min}$ at $14,000 \times \mathrm{g}$. The resulting pellet was re-suspended in $500 \mu \mathrm{l}$ of $1 \mathrm{M} \mathrm{NaOH}$ for posterior protein quantification, while the supernatant was neutralized with $3 \mathrm{M} \mathrm{KOH} / 1.5 \mathrm{M}$ Tris, and centrifuged again for $10 \mathrm{~min}$ at $14,000 \times g$. The supernatant was collected and immediately analyzed by reverse-phase high performance liquid chromatography (HPLC), at a wavelength of $254 \mathrm{~nm}$. The chromatographic apparatus was a Waters ${ }^{\circ}$ Breez $^{\mathrm{TM}}$ system, consisting of a 1525 Binary HPLC Pump and a Waters 2487 Dual Wavelength Absorbance Detector. The column was a LiChrospher ${ }^{\bullet} 100 \mathrm{RP}-18(5 \mu \mathrm{m})$ LiChroCART $^{\circ} 125-4$ (Merck) and the analysis was performed using the software Waters ${ }^{\circ}$ Breeze $^{\mathrm{TM}}$ HPLC software. An isocratic elution with $100 \mathrm{mM}$ phosphate buffer $\left(\mathrm{KH}_{2} \mathrm{PO}_{4}\right), \mathrm{pH} 6.5$ and $1.2 \%(\mathrm{v} / \mathrm{v})$ methanol was performed with a flow rate of $1 \mathrm{ml} / \mathrm{min}$. To determine the nucleotide concentrations, standard curves of ATP, ADP and AMP were previously run. The required time for each analysis was $5.5 \mathrm{~min}$. The adenylate energy charge (EC) was then calculated as EC = (ATP $+1 / 2 \mathrm{ADP}) /(\mathrm{ATP}+\mathrm{ADP}+\mathrm{AMP})$.

\subsection{Quantitative real-time PCR}

Total RNA was extracted using Aurum ${ }^{\mathrm{TM}}$ Total RNA Mini Kit (BioRad, CA, USA) according to the manufacturer's instructions. cDNA was obtained by retrotranscription of $2 \mu \mathrm{g}$ of total RNA with iScript cDNA synthesis kit (Bio-Rad, CA, USA), in a final $40 \mu \mathrm{l}$ volume. The RT-qPCR mixture contained $5 \mu$ l of SsoFast ${ }^{\mathrm{Tm}}$ EvaGreen ${ }^{\circ}$ supermix (Bio-Rad, CA, USA), $500 \mathrm{nM}$ of each primer and $12.5 \mathrm{ng}$ of cDNA sample, to a total volume of $10 \mu \mathrm{L}$. The reaction was run on a $\mathrm{CFX}^{\mathrm{TM}}$ Real-Time system (Bio-Rad, CA, USA) according to the following protocol: $30 \mathrm{~s}$ at $95^{\circ} \mathrm{C}$, 40 cycles of $5 \mathrm{~s}$ at $95^{\circ} \mathrm{C}$ and $5 \mathrm{~s}$ at $62^{\circ} \mathrm{C}$ and, at the end, an additional step (temperature ramp from $65^{\circ} \mathrm{C}$ to $95^{\circ} \mathrm{C}$ with increments of $0.5^{\circ} \mathrm{C}$ per cycle) was used for the melting curves. The expression was normalized with TBP (TATA box binding protein) and $18 S$ (18S ribosomal RNA) as references. All samples were analyzed in duplicate. The PCR primers are detailed in Supplemental table S1.

\subsection{Mitochondrial DNA copy number}

Total DNA was extracted by PureLink ${ }^{\mathrm{TM}}$ Genomic DNA MiniKit (Invitrogen, Carlsbad, CA, USA) according to the manufacturer's protocol. Mitochondrial DNA content was measured by a real-time qPCR method. Cyt B gene was used to represent the mitochondrial DNA (mtDNA) and $b 2 m$ gene was used to represent nuclear DNA (nDNA). Relative mtDNA copy numbers were assessed after $C y t B$ normalization by $b 2 m$ gene copy number. Rat primers for $C y t B$ were: forward 5'-TACGCTATTCTACGCTCCATTC-3', reverse 5'-GCCTCCGATTCATGT TAAGACTA-3'; primers for $b 2 m$ were: forward $5^{\prime}$ - AGAGAACTCAACG GTGGCAG-3', reverse 5'- CGACCGCACACTATAGGGAC-3'. The $10 \mu 1$ PCR reaction contained $5 \mu$ of SsoFast ${ }^{\mathrm{TM}}$ EvaGreen ${ }^{\circ}$ supermix (Bio-Rad), $500 \mathrm{nM}$ of each DNA primer and $25 \mathrm{ng}$ of total DNA template. Amplification program consisted in $2 \mathrm{~min}$ at $98^{\circ} \mathrm{C}$, followed by $40 \mathrm{cy}$ cles of $5 \mathrm{~s}$ at $98^{\circ} \mathrm{C}$ and $5 \mathrm{~s}$ at $62^{\circ} \mathrm{C}$. The amplification specificity was assessed at the end of the amplification by a melting curve between 65 and $95^{\circ} \mathrm{C}$, using an increment of $0.5^{\circ} \mathrm{C}$ in each step. The reactions were performed on a $\mathrm{CFX}^{\mathrm{Tm}} 96$ Real-Time system (Bio-Rad, CA, USA). The normalized expression was calculated by the comparative quantification algorithm $\Delta \Delta \mathrm{C}_{\mathrm{t}}$ (CFX Manager ${ }^{\mathrm{rM}} 3.1$ software, Bio-Rad).

\subsection{Measurement of nuclear DNA methyltransferase I (DNMT1)}

Nuclear fractions were obtained according to a subcellular fractioning protocol described elsewhere (Dimauro et al., 2012), with slight modifications. Briefly, cells were scraped from the dishes with PBS/ EDTA and centrifuged at $200 \times g$ for $4 \mathrm{~min}$. The pellets were washed with $1 \mathrm{ml}$ of cold PBS and centrifuged again at $300 \times g$ for $7 \mathrm{~min}$. The supernatant was discarded and the pellet was resuspended in $500 \mu \mathrm{l}$ of STM buffer (250 mM sucrose, $50 \mathrm{mM}$ Tris- $\mathrm{HCl} \mathrm{pH} \mathrm{7.4,} 5 \mathrm{mM} \mathrm{MgCl}_{2}$; supplemented with $1 \mu \mathrm{l} / \mathrm{ml}$ protease inhibitor cocktail (P8340, SigmaAldrich) and homogenized using a tight pestle attached to a potter 
A

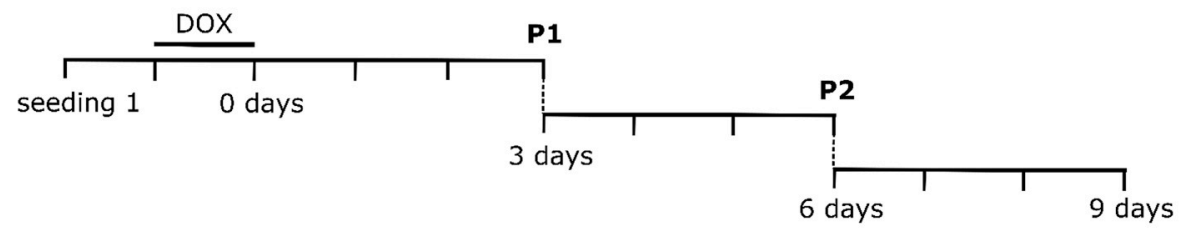

B

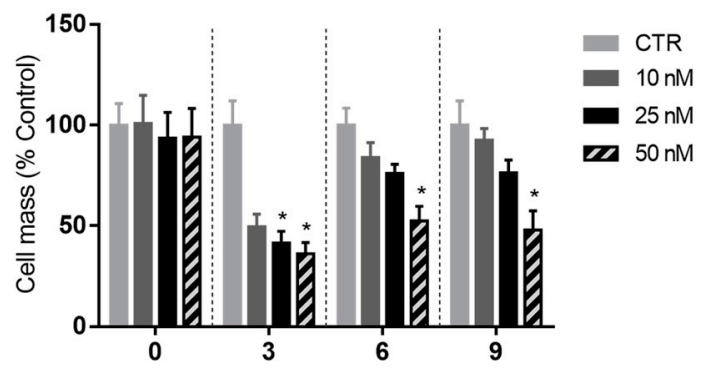

Recovery Time (days)

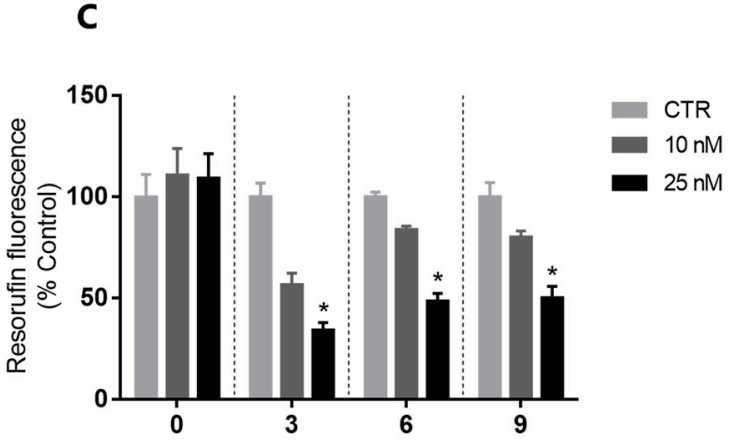

Recovery Time (days)

Fig. 1. Effect of DOX pretreatment on H9c2 viability. (A) Cells were incubated with 10, 25 and $50 \mathrm{nM}$ DOX for 24 h. Following the single treatment, the cells were cultured in drug-free media until day 9. P refers to a cell passage. (B) Cell mass and (C) metabolic viability were determined by using the SRB and resazurin methods, respectively, at days 0, 3, 6 and 9. Data are expressed as mean \pm SEM of four independent experiments; *p $<0.05$, compared to control.

homogenizer (Heidolph, Germany) set at $500 \mathrm{rpm}$ and with 50 strokes. After $30 \mathrm{~min}$ on ice, the cell homogenate was vortexed at maximum speed and further centrifuged at $700 \times g$ for $15 \mathrm{~min}$. The pellet was resuspended in STM $(250 \mu \mathrm{l})$, vortexed for $15 \mathrm{~s}$ and centrifuged at $500 \times g$ for $15 \mathrm{~min}$. This last wash was repeated again but followed by a $1000 \times g$ centrifugation. Then, the pellet was resuspended in $250 \mu \mathrm{l}$ of NET buffer (20 mM HEPES pH 7.9, $1.5 \mathrm{mM} \mathrm{MgCl}_{2}, 0.5 \mathrm{M} \mathrm{NaCl}, 0.2 \mathrm{mM}$ EDTA, 20\% glycerol and 1\% Triton-X-100; supplemented with $1 \mu \mathrm{l} / \mathrm{ml}$ protease inhibitor cocktail), vortexed for $15 \mathrm{~s}$ and incubated on ice for $30 \mathrm{~min}$. Lastly, the crude nuclear fraction was lysed by sonication $(3 \times 10 \mathrm{~s}$, with $20 \mathrm{~s}$ pauses) and, after a centrifugation of $9000 \times g$ for $30 \mathrm{~min}$, the supernatant was recovered as the final nuclear fraction. Nuclear DNMT1 amounts were determined using a DNMT1 ELISA kit (ab113469, Abcam, Cambridge, UK) according to the manufacturer's instructions and by reading the absorbance in a Cytation ${ }^{\mathrm{TM}} 3$ microplate reader (BioTek, USA) at $450 \mathrm{~nm}$.

\subsection{Immunostaining}

For immunocytochemistry, H9c2 cells were seeded in 6 well-plates with a glass coverslip in each well, at a density of $8.0 \times 10^{3}$ cells $/ \mathrm{cm}^{2}$, in a final volume of $2 \mathrm{ml}$ per well. The wells were washed twice with filtered PBS and fixed with 4\% paraformaldehyde in PBS for $15 \mathrm{~min}$. Then, cells were washed three times with PBS-T (PBS $+0.05 \%$ Tween 20 ) and permeabilized with $0.2 \%$ Triton X-100 in PBS ( 2 min, RT). Cells were washed twice with PBS-T and treated with $\mathrm{HCl} 2 \mathrm{~N}$ (20 min, RT) to denature the DNA and allow binding of the primary antibody to methylated DNA. After five washes with PBS-T, cells were blocked with $3 \%$ BSA in PBS-T (30 min, $\left.37^{\circ} \mathrm{C}\right)$. The anti-5-methylcytosine $(5 \mathrm{mC})$ antibody (ab73938, Abcam; 1:100 in blocking solution) was added and incubated for $5 \mathrm{~h}$ at $4{ }^{\circ} \mathrm{C}$. Cells were then rinsed with PBS-T three times for $5 \mathrm{~min}$. Primary antibody was detected using Alexa Fluor-488 conjugated secondary antibody (A11001, Invitrogen; 1:200 in blocking solution) after $2 \mathrm{~h}$ incubation at RT in the dark. Next, cells were incubated with Hoechst 33342 in PBS-T ( $3 \mu \mathrm{g} / \mathrm{mL}$; B2261, Sigma-Aldrich) for $10 \mathrm{~min}$ at RT, followed by two washes with PBS-T for $2 \mathrm{~min}$, and mounted with Fluorescence Mounting Medium (S3023, DAKO). Images were taken with a Nikon eclipse Ti-S fluorescence microscope.

\subsection{Statistical analysis}

Statistical analyses were performed using SPSS version 23.0 (IBM, NY, USA) and GraphPad Prism 6 (GraphPad Software, Inc., La Jolla, CA, USA). Nonparametric Mann-Whitney $U$ test and Kruskal-Wallis H-test followed by Dunn's post hoc analysis were used. The data is presented as mean \pm SEM. Differences were considered statistically significant at $\mathrm{p}<0.05$.

\section{Results}

\subsection{Effects of DOX pretreatment on cell viability}

In our experimental design, we tested therapeutically relevant concentrations of DOX (Greene et al., 1983) and investigated the longterm effects of that treatment after a prolonged recovery time. For this, H9c2 cells were treated with DOX for $24 \mathrm{~h}$, after which the cells were washed, and kept in culture for nine days more, being passaged twice (Fig. 1A). The SRB assay was used to investigate the effects of DOX on cell mass, at four distinct time-points (Fig. 1B). After the initial treatment with DOX (10-50 nM) (0 days of recovery), no significant differences were observed on cell mass between control group and DOXtreated cells. However, at the second time-point (3 days) significant loss of total cell mass was observed, which seemed to gradually recover at the two last time points. We next evaluated the effects of the sub-toxic DOX concentrations (10 and $25 \mathrm{nM}$ ) on metabolic viability (Fig. 1C). Even though $25 \mathrm{nM}$ DOX significantly decreased resazurin reduction at days 3, 6 and 9, an overall improvement of cell viability was observed over time. The concentrations of 10 and $25 \mathrm{nM}$ were selected for the next follow-up experiments.

\subsection{DOX treatment resulted in hypertrophy and cell cycle arrest}

To determine alterations on $\mathrm{H} 9 \mathrm{c} 2$ cell morphology and $\Delta \Psi_{\mathrm{m}}$ after 0 and 9 days of recovery, control and $25 \mathrm{nM}$ DOX-treated cells were 
A
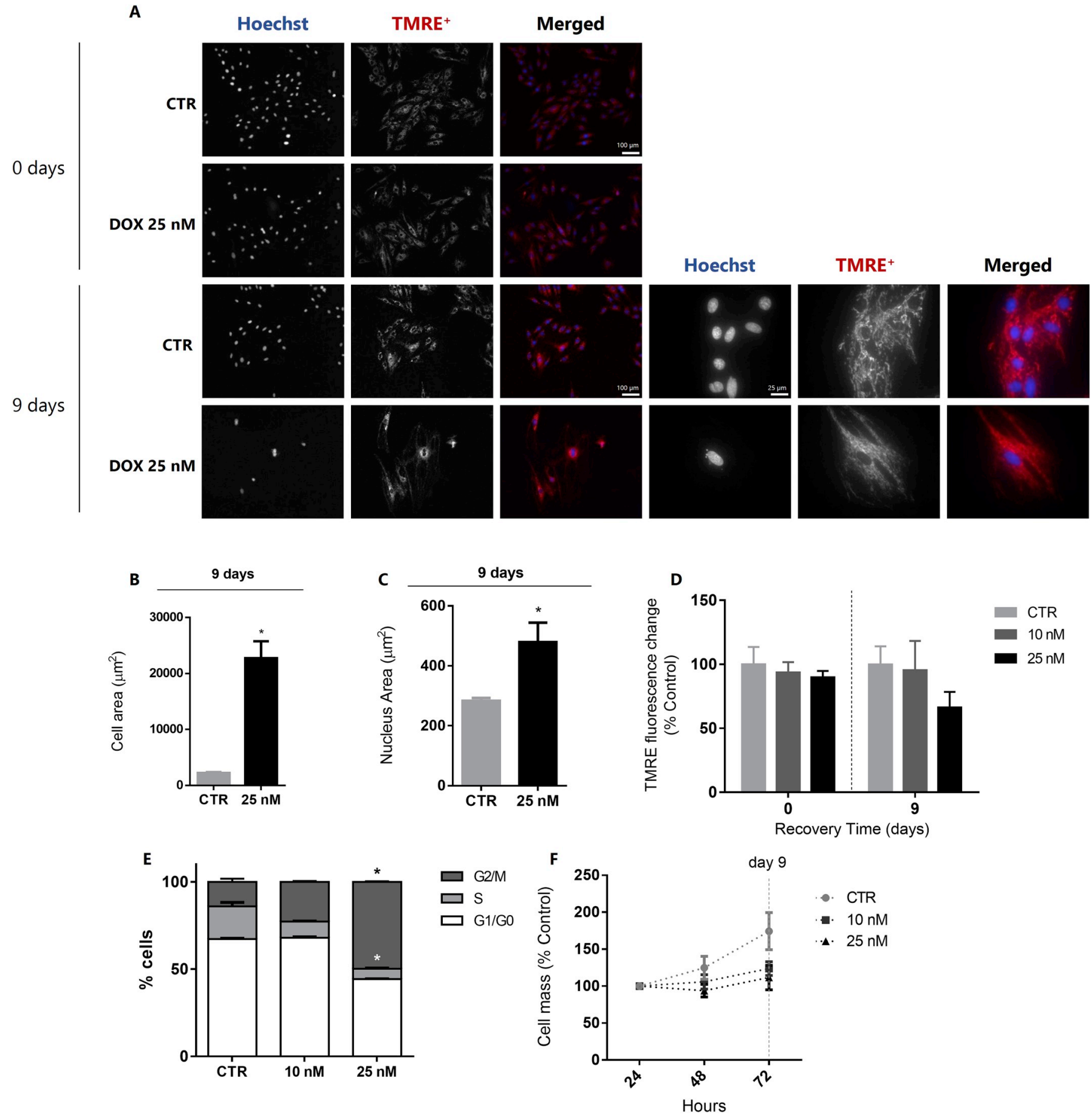

Fig. 2. DOX effects on H9c2 cells morphology and cell cycle. (A) At 0 and 9 days of recovery time, epifluorescence microscopy images of nuclei and polarized mitochondria were collected from control and $25 \mathrm{nM}$ DOX-treated H9c2 cells for $24 \mathrm{~h}$. Scale bar; 100 and $25 \mu \mathrm{m}$. (B-C) At day 9, the nuclear and cellular sizes were measured and expressed as percentage of controls. Error bars indicate SEM from measurements of multiple cells of three independent experiments. (D) TMRE ${ }^{+}$ accumulation was measured in a plate reader at day 0 and 9 and data is represented as mean \pm SEM percentage of control for each specific time-point from four independent experiments. (E) Cell cycle was analyzed by flow cytometry using propidium iodide in untreated and DOX-treated cells at day 9. Data are expressed as percentage of cells in G2/M, S and G1/G0 \pm SEM from at least three independent experiments. (F) At day 6 cells were seeded and cell mass was evaluated by SRB from day 7 to day 9. Data are expressed as mean \pm SEM of three independent experiments; *p $<0.05$, compared to control.

labeled with Hoechst and $\mathrm{TMRE}^{+}$and visualized by fluorescence microscopy (Fig. 2A). Immediately after the initial $24 \mathrm{~h}$ treatment with DOX, no morphological differences were found between groups (Fig. 2A). However, at day 9, significantly larger nuclei were observed in $25 \mathrm{nM}$ DOX-treated cells compared to non-treated cells (Fig. 2C). Also, treated cells were hypertrophied, with average total cellular area significantly larger than in the controls (Fig. 2B). Similar, but milder, morphological changes were observed in cells treated with $10 \mathrm{nM}$ DOX (data not shown). For the analyses of $\Delta \Psi_{\mathrm{m}}$, the membrane permeable cation $\mathrm{TMRE}^{+}$was used, which accumulates in the mitochondrial matrix depending on the $\Delta \Psi_{\mathrm{m}}$. High accumulation of the dye inside mitochondria leads to fluorescence quenching, which means the total dye fluorescence decreases as the organelles accumulate TMRE ${ }^{+}$. DOX effect on $\Delta \Psi_{\mathrm{m}}$ in $\mathrm{H} 9 \mathrm{c} 2$ cells was analyzed using the quenching 
A

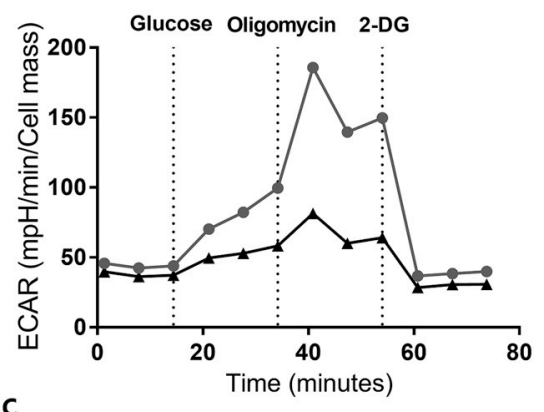

C
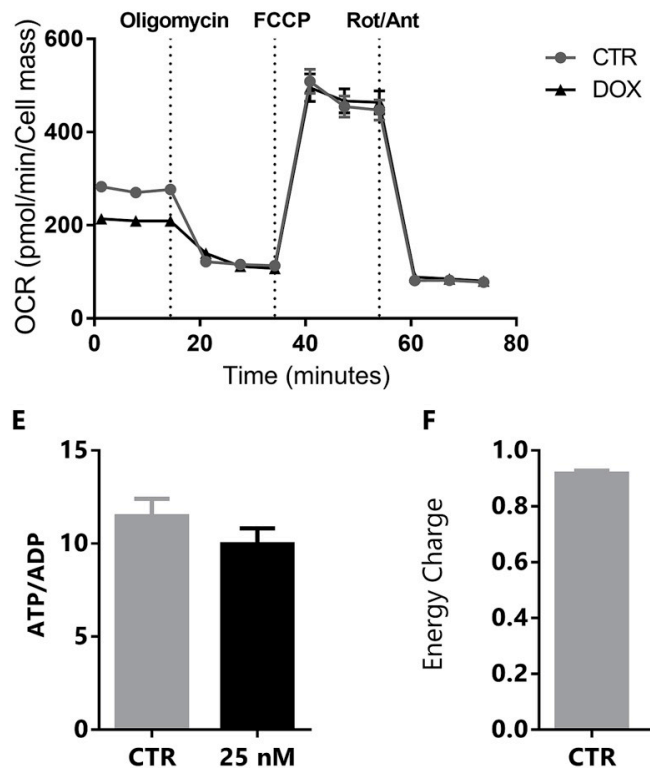
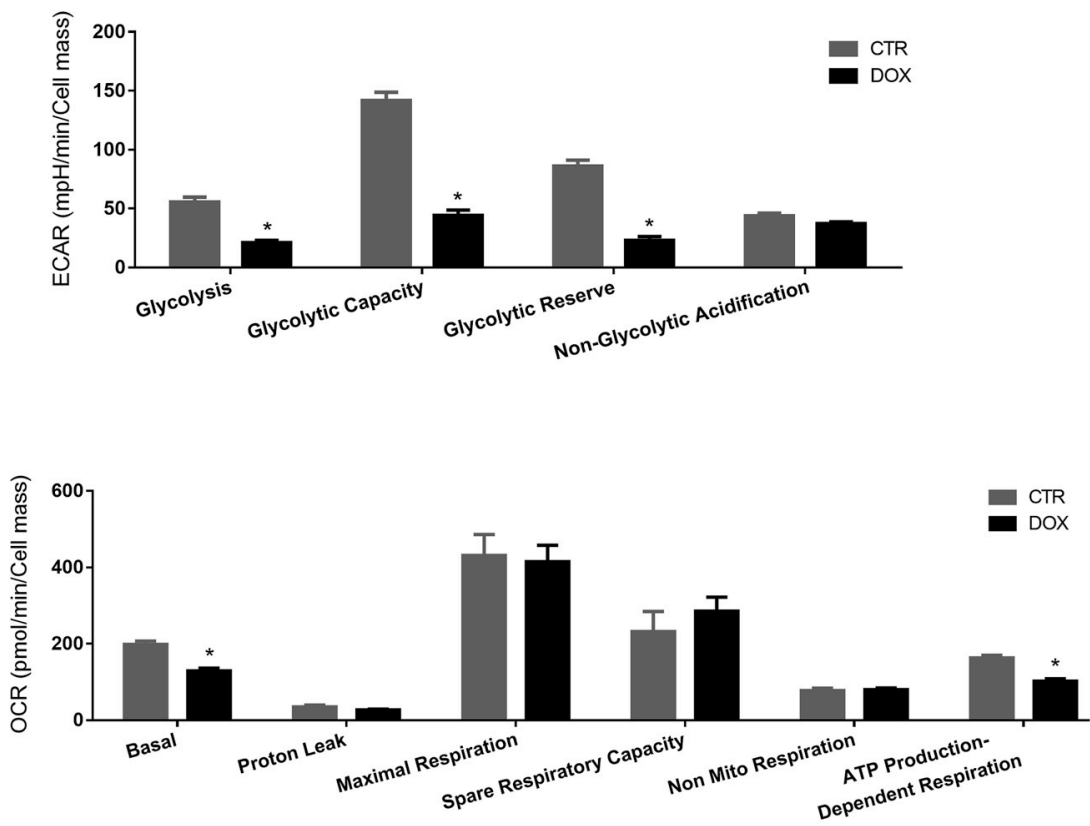

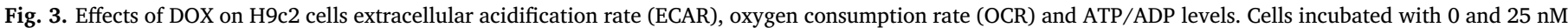

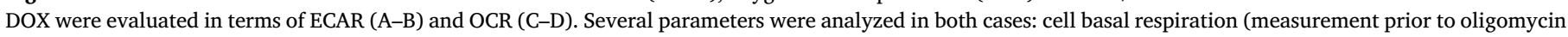

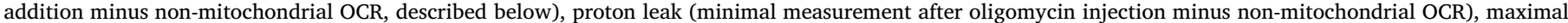

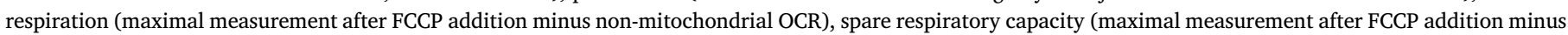

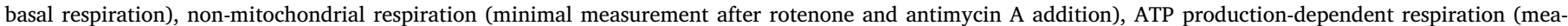

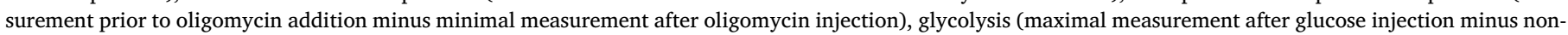

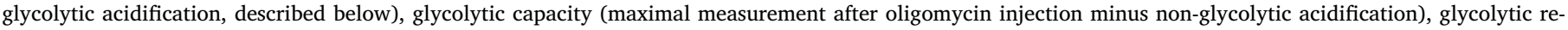

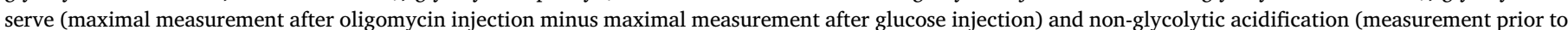

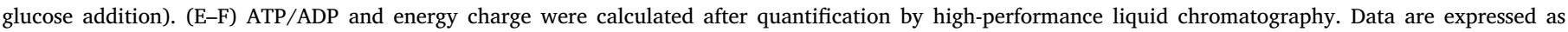
mean \pm SEM of at least four independent experiments; $\mathrm{p}<0.05$, compared to control.

approach. Our results showed no significant changes on $\Delta \Psi_{\mathrm{m}}$ in DOXtreated H9c2 cells, compared to controls (Fig. 2D). We next evaluated DOX persistent effects on cell cycle, also at the last time-point. At day 9, DOX treatment induced a cell cycle arrest in G2/M (Fig. 2E). Unlike control cells, in which the majority of $\mathrm{H} 9 \mathrm{c} 2$ cells ( $\approx 67 \%)$ were in G1/ G0 phase, DOX-treated cells had a dose-dependent increase of cells in $\mathrm{G} 2 / \mathrm{M}$ and a reduction in the population of cells in S and G1/G0. As a consequence, DOX-treated cells exhibited a slower proliferation rate, observed by the growth curve performed from day 7 to day 9 (Fig. 2F).

\subsection{DOX decreased extracellular acidification and reduced basal respiration of $\mathrm{H} 9 \mathrm{c} 2$ cells}

DOX cardiotoxicity has been previously shown to alter cellular metabolic fluxes (Carvalho et al., 2010; Strigun et al., 2012). Our next step was to evaluate whether DOX altered the OCR and ECAR at nanomolar treatments. At day 9, OCR and ECAR were measured using a Seahorse $\mathrm{XF}^{\mathrm{e}} 96$ Extracellular Flux analyzer. Cells treated with $25 \mathrm{nM}$
DOX had decreased glycolysis compared to control cells ( $\sim 60 \%$ less ECAR), as well as decreased glycolytic capacity and reserve, indicative of impaired glycolytic metabolism (Fig. 3A and B). Regarding OCR measurements, basal respiration and ATP production-dependent respiration was significantly decreased in DOX-treated cells, the latter most likely resulting from the first observation (Fig. 3C and D). However, other parameters including maximal respiration and spare respiration capacity were not altered (Fig. 3C and D). Similarly, neither the ratio ATP/ADP nor energy charge were altered by the treatment (Fig. 3E and F).

\subsection{Sublethal DOX treatment was associated with transcriptional alterations of mitochondrial-relevant genes}

Because gene expression changes were previously described in a persistent model of cardiomyopathy (Berthiaume and Wallace, 2007b), we examined if DOX treatment would induce changes in mRNA expression in H9c2 cells throughout the time course of the treatment 


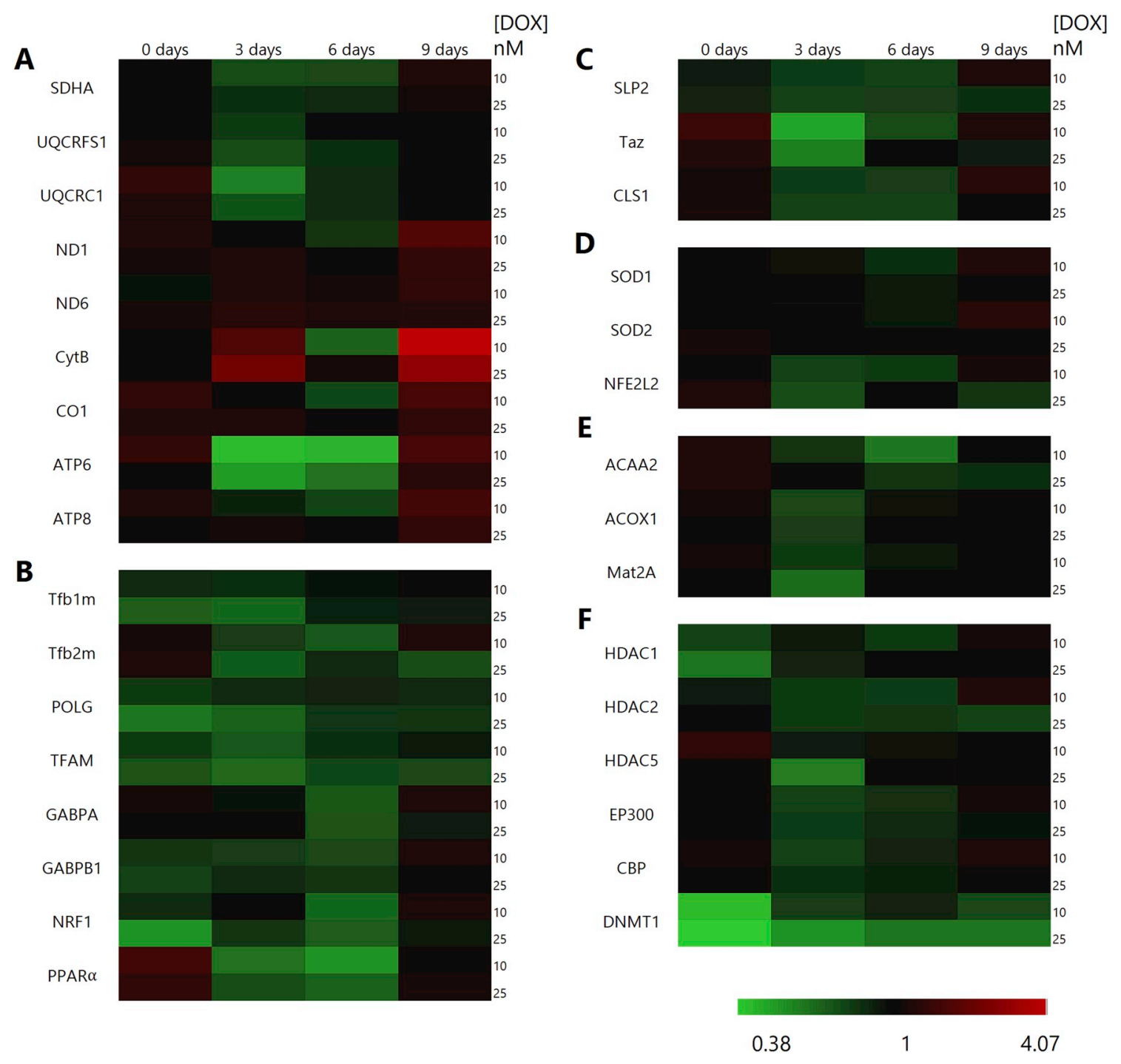

Fig. 4. Heat map diagram of average gene expression detected by RT-PCR, belonging to the following categories: OxPhos subunits (A), mitochondrial biogenesis (B), cardiolipin metabolism (C), antioxidants (D), cell metabolism (E) and epigenetic modulators (F). Green indicates down-regulation and red indicates upregulation. Each column represents a day of recovery time, namely $0,3,6$ and 9 days. Gene expression was quantified for both DOX concentrations, 10 and $25 \mathrm{nM}$. Data are expressed as mean of four independent experiments and compared to control. (For interpretation of the references to colour in this figure legend, the reader is referred to the Web version of this article.)

(Fig. 4). Several functional categories of genes were analyzed, namely oxidative phosphorylation (OxPhos) subunits (Fig. 4A), mitochondrial biogenesis (Fig. 4B), cardiolipin metabolism (Fig. 4C), antioxidant defenses (Fig. 4D), cell metabolism (Fig. 4E) and epigenetic modulators (Fig. 4F). These genes were chosen based on previous reports demonstrating persistent alterations on gene expression profiles after DOX exposure (Berthiaume and Wallace, 2007b; Ferreira et al., 2017). It is worth noting that gene expression alterations varied according to the time-point analyzed, and it was not always possible to find clear patterns of gene expression along the protocol. Also, the analyzed transcripts did not present a dose-dependent response most of the times, suggesting that, in this model, the different pharmacological concentrations may induce different cellular responses. Interestingly, the results revealed a general increase in the expression of genes encoded by the mtDNA, including ND1, ND6, CytB, CO1, ATP6 and ATP8 (Fig. 4A). Among the overexpressed mtDNA-encoded genes, ND1, CytB, CO1 and ATP8 were particularly overexpressed $(\mathrm{p}<0.05)$ in $10 \mathrm{nM}$ DOX-treated cells (Fig. 5A).

\subsection{DOX induced DNMT1 downregulation associated with expression of mitochondrial-encoded genes}

Since there was a tendency for an increased abundance of mitochondrial transcripts, we then analyzed mtDNA copy number to infer a possible relationship between them. mtDNA content was monitored by measuring the relative copy number of mitochondrial encoded gene $C y t B$ compared to the nuclear gene $b 2 m$, using RT-PCR (Fig. 5B). The copy number of mtDNA was not significantly different between treatments at any of the time-points (day $0: \mathrm{p}$-value $=0.124$; day 3 : $\mathrm{p}$ value $=0.084$; day $6: \mathrm{p}$-value $=0.664$; day 9: $\mathrm{p}$-value $=0.146$ ). Additionally, we confirmed the gene expression levels of two important mitochondrial-related proteins usually associated with mtDNA content, the mitochondrial transcription factor A (TFAM) and the mitochondrial-specific polymerase gamma (POL $\gamma$ ). TFAM is involved in mtDNA packaging and mitochondrial gene expression regulation and POL $\gamma$ is essential for mtDNA replication and maintenance. Both tfam and polg transcript levels decreased in DOX-treated cells (mostly at day 0 and 3) 
A

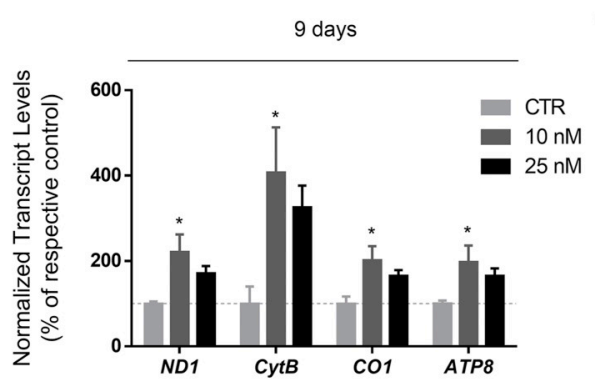

B

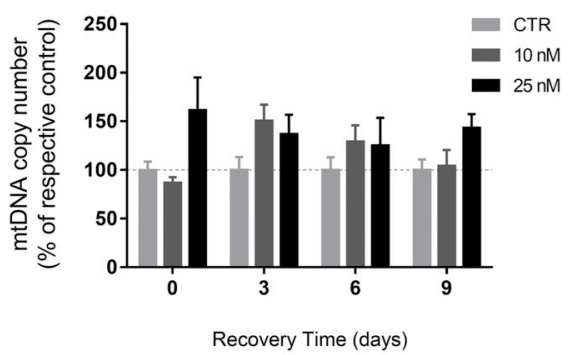

G

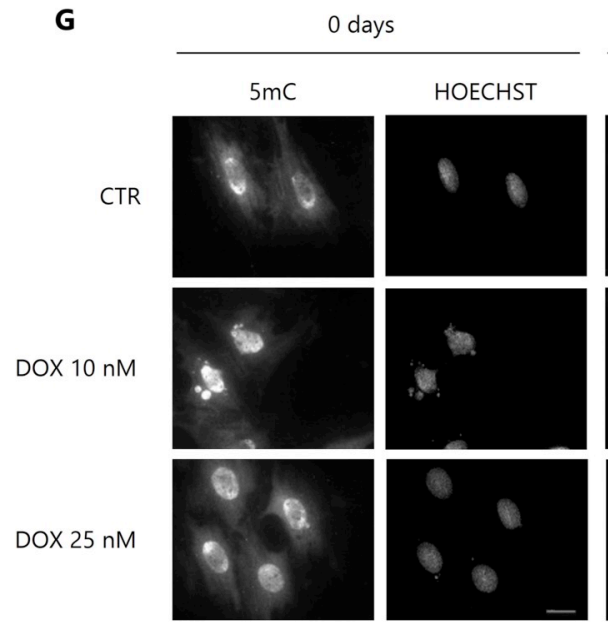

days c

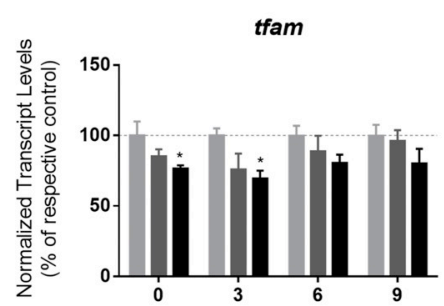

$\mathbf{E}$
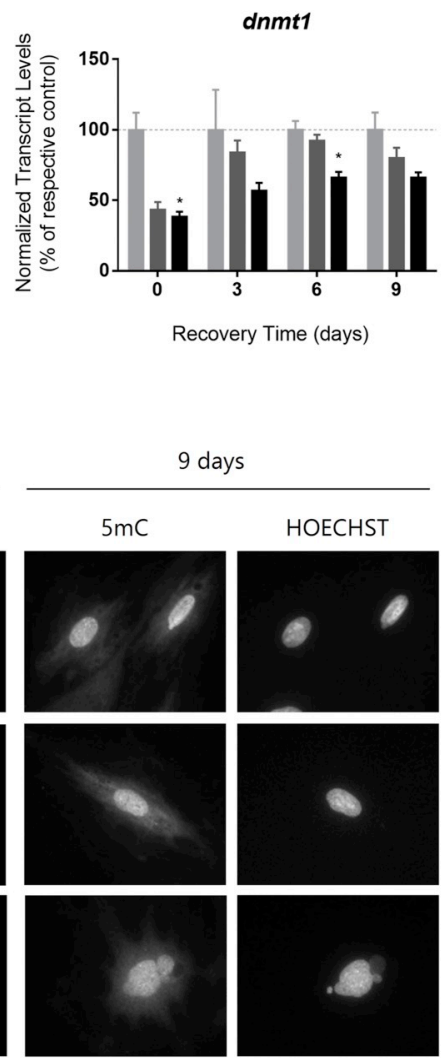

D

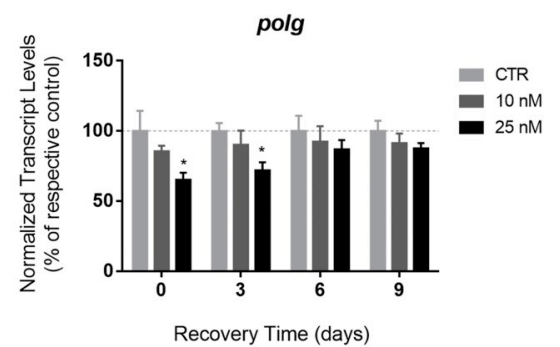

$\mathbf{F}$

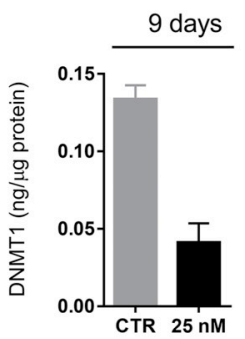

H

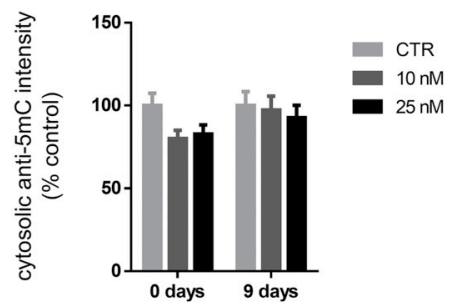

I

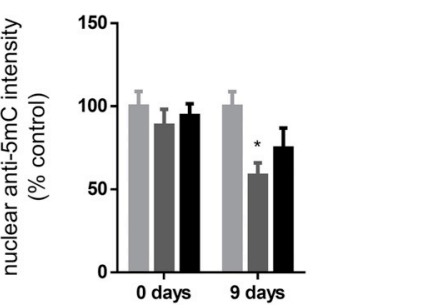

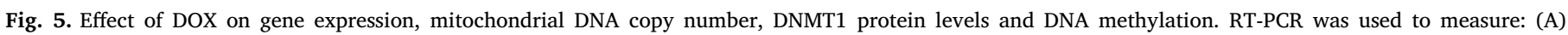

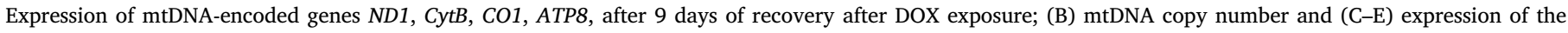

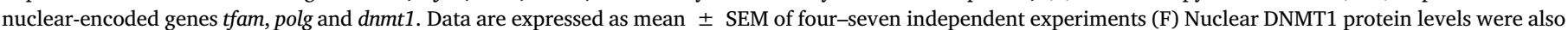

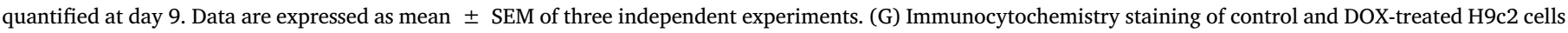

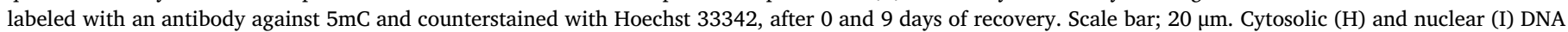

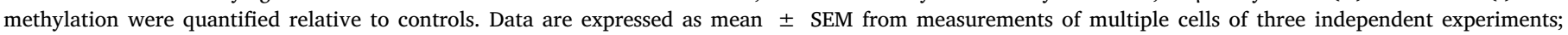
* $\mathrm{p}<0.05$ compared to control.

(Fig. 5C and D). Interestingly, DNMT1 gene, encoding the primary DNA methyltransferase responsible for the maintenance of DNA methylation patterns during cell replication, was downregulated in all four timepoints, although more expressively at day 0 and 6 (Fig. 5E). Nuclear DNMT1 protein levels were assessed by a commercial ELISA kit and a similar tendency (although not statistically significant) was observed, with DOX-treated cells presenting lower levels of DNMT1 (Fig. 5F). Immunocytochemistry examination of $\mathrm{H} 9 \mathrm{c} 2$ cells labeled with anti-5mC antibody revealed loss of signal in $10 \mathrm{nM}$ DOX-treated cells, as well as the presence of micronuclei in 10 and $25 \mathrm{nM}$ DOX-treated cells (Fig. 5G-I). Recent evidence suggests the presence of methylated cytosine in mtDNA, namely within the D-loop region, a hypervariable region where the main regulatory elements for mtDNA replication and expression are located (Abhyankar et al., 2009; Bellizzi et al., 2013). Also, DNMT1 seems to modulate mitochondrial transcription through the regulation of mtDNA methylation (He et al., 2017; Shock et al.,
2011). Our findings suggest that in response to low DOX concentration, a DNMT1-based mechanism of mtDNA expression regulation seems to happen, although this was not directly measured.

\subsection{Nanomolar DOX-mediated mitochondrial adaptation protects against a subsequent DOX treatment}

Considering the mitochondrial data obtained so far, our next question was whether the apparent mitochondrial adaptation of DOXtreated cells could lead to an increased resistance to a second-hit stressor. To assess this, after nine days of recovery, H9c2 cells were again treated with DOX for $24 \mathrm{~h}$, but this time with higher concentrations $(0.2,0.5$ and $1 \mu \mathrm{M}$ ) (Fig. $6 \mathrm{~A}$ ), and cytotoxicity was measured by the SRB and resazurin methods (Fig. 6B and C). Although there was a decrease in cell mass for all the four treatments, the effect was less pronounced for the 10 and $25 \mathrm{nM}$ pre-treated cells, comparing with 
A

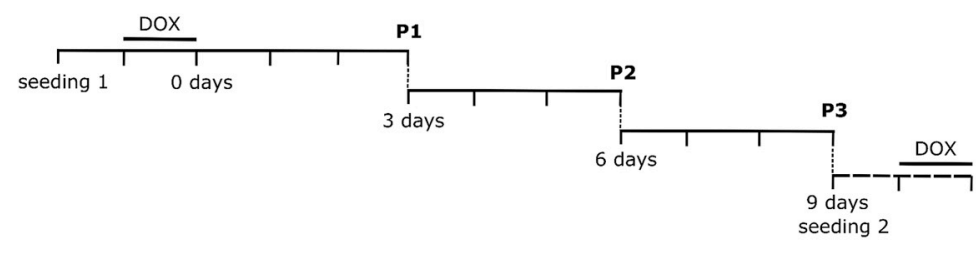

C

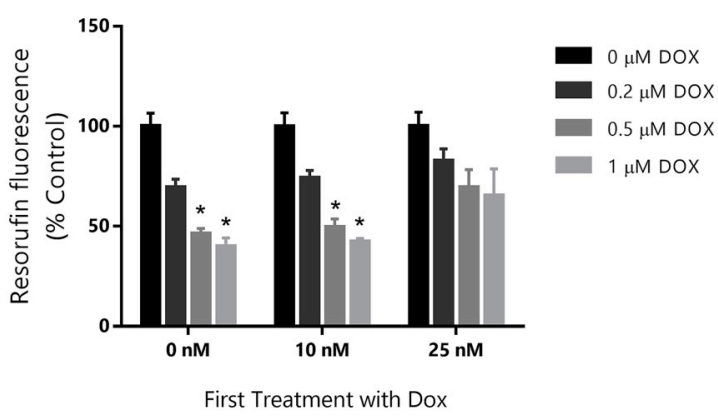

E

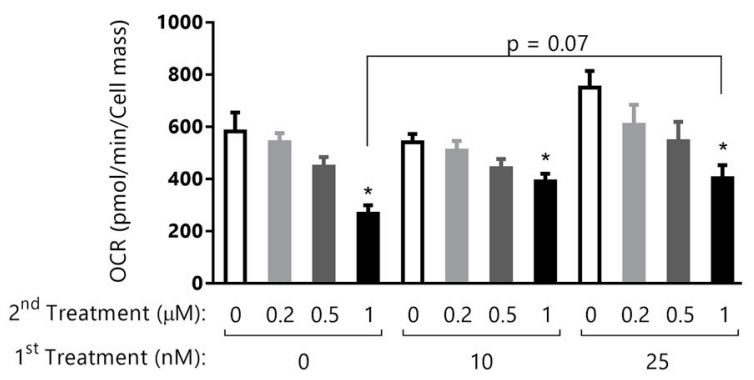

B

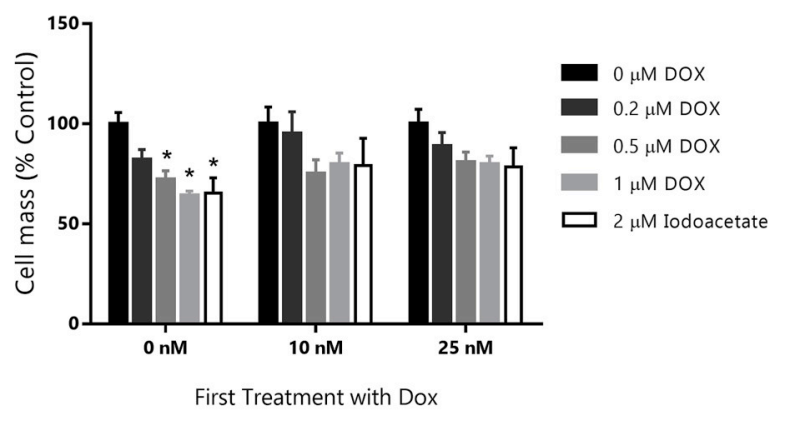

Basal

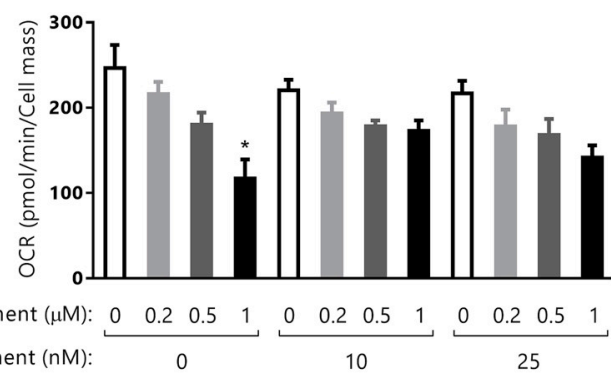

$\mathbf{F}$

Fig. 6. Effect of pretreatment with DOX on H9c2 cells response to second-hit stress (A). After the initial protocol, cells were seeded again and exposed to DOX (0.2, 0.5 and $1 \mu \mathrm{M})$ or iodoacetate $(2 \mu \mathrm{M})$ for $24 \mathrm{~h}$. P refers to a cell passage. Toxicity was evaluated by SRB as the post-treatment percentage of cell mass (B) and by metabolic reduction of resazurin (C). Data are expressed as mean \pm SEM of four-six independent experiments. (D-F) Seahorse XF 96 analyzer was used to evaluate mitochondrial respiration rates and determine several respiratory parameters including basal respiration (D), maximal respiration (E) and spare respiratory capacity (F). These results are expressed as mean \pm SEM of four independent experiments. * $\mathrm{p}<0.05$ compared to no DOX treatment group.

control cells (for $1 \mu \mathrm{M}$ DOX, cell mass decreased $\sim 20 \%$ in DOX pretreated cells in contrast to $\sim 36 \%$ in control cells) (Fig. 6B). Similarly, the decrease of metabolic activity was much less pronounced in the $25 \mathrm{nM}$ DOX pre-treated cells when compared with the $0 \mathrm{nM}$ DOX control (Fig. 6C). The pre-treatment also improved the resistance of H9c2 against iodoacetate, an inhibitor of glycolysis ( $\sim 13 \%$ improvement of cell viability in DOX pre-treated cells compared to DOX-naïve cells), consistent with the reduced glycolytic metabolism observed in $25 \mathrm{nM}$ DOX-treated cells. (Fig. 6B). The impact of the preconditioning on mitochondrial adaptation was further validated by mitochondrial oxygen consumption rate measurements (Fig. 6D-F). Basal respiration rates did not change significantly (Fig. 6D); however, maximal respiration (Fig. 6E) and spare respiratory capacity (Fig. 6F) showed higher levels in $25 \mathrm{nM}$ DOX cells compared with the non-pre-treated cells. In order to discard the possibility that this pre-conditioning treatment with DOX could induce cross-resistance also in tumor cells, we performed the same protocol in Hs-578T and MDA-MB-231 cell lines, models of human breast/mammary gland carcinoma (Supplemental Fig. 1). No differences were observed in cell viability after the second exposure to DOX between control, $10 \mathrm{nM}$ - and $25 \mathrm{nM}$-treated groups.

\section{Discussion}

It has previously been shown that DOX treatment in vivo induces mitochondrial/metabolic reprogramming (Carvalho et al., 2010). In the current investigation, we aimed to study the delayed response of H9c2 cells to nanomolar doses of DOX and the possible induction of an adaptive response, increasing the tolerance to a subsequent higher dose. We confirmed decreased cytotoxicity after clinically relevant DOX treatment in cells that were previously treated with DOX at low clinical doses, supporting the hypothesis of a protective mechanism.

We first demonstrated increased cell cycle arrest in G2/M and hypertrophy in nanomolar DOX-treated H9c2 cells. Similar hypertrophic behavior has been previously observed in $\mathrm{H} 9 \mathrm{c} 2$ cells, as well as in animal models of DOX-induced cardiomyopathy (Merten et al., 2006; Pillai et al., 2016; Richard et al., 2011). Oyama et al. reported that $\mathrm{H}_{2} \mathrm{O}_{2}$ and $1 \mu \mathrm{M}$ DOX ( $2 \mathrm{~h}$ ) also induced cell cycle arrest in G2/M with increased p21 expression, a well-established regulator of the cell cycle (Oyama et al., 2011). Their findings implicate H9c2 cell hypertrophy as a late event secondary to cell cycle arrest. Activation of p53 by DOX usually results in the overexpression of the p53-target gene Bax, leading 


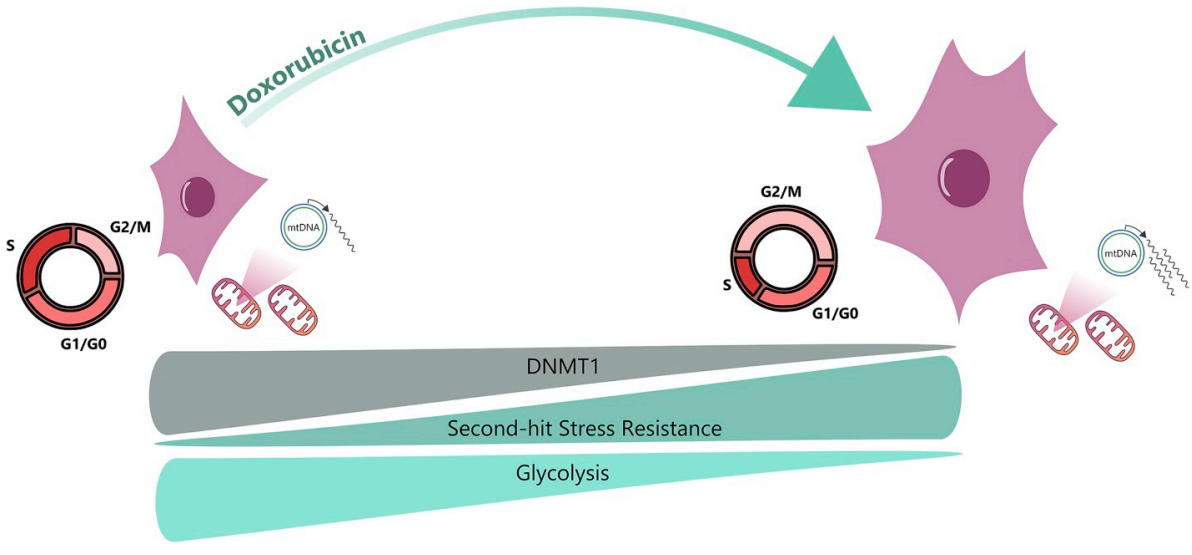

Fig. 7. Schematic representation of the proposed mechanism of subclinical DOX exposure, resulting in second-hit stress resistance. Nanomolar DOX treatment affects $\mathrm{H} 9 \mathrm{c} 2$ cells triggering an arrest at G2/M, cell hypertrophy, overexpression of mtDNA-encoded genes, DNMT1 down-regulation and decreased glycolytic activity. Also, DOX pre-treated cells showed to be more resistant to a second treatment. Thus, we propose that the treatment with sublethal DOX concentrations stimulates compensatory responses, which may serve to decrease damage resulting from subsequent treatments with higher concentrations. to overexpression of the corresponding pro-apoptotic protein Bax, which translocates to the mitochondrial membrane leading to apoptosis. Alternatively, under stress conditions, such as DNA damage or oxidative stress, upregulation of p53 activity results in increased p21 transcription that leads to cell cycle arrest (Garner and Raj, 2008; Venkatakrishnan et al., 2008). These phenomena can either give time for DNA repair and cell survival, or can lead to a senescence-like phenotype (Eom et al., 2005; Maejima et al., 2008), which could eventually lead to mitotic catastrophe and cell death. Thus, the possible beneficial effects of preconditioning can be counterbalanced with less positive outcomes that need to be carefully noted and considered.

Previous authors have reported a shift of energy production in DOX damaged hearts (Carvalho et al., 2010; Zhao et al., 2014). In our model, nanomolar DOX treatment inhibited glycolysis, in accordance with the slower proliferative behavior, but did not cause major effects on maximal mitochondrial respiration capacity or total ATP production. In addition, gene expression analysis showed an increase in mitochondrial transcripts after nine days of recovery, and these increased levels seem to be independent from mtDNA content, as confirmed by mtDNA copy number, and from tfam and polg levels.

Evidence for the existence of 5-methylcytosines $(5 \mathrm{mC})$ and 5-hydroxycytosines $(5 \mathrm{hmC})$ and their influence on mtDNA are becoming stronger due to the improvement and development of sensitive techniques capable of detecting low-levels of methylation in the mtDNA, supporting the presence of dynamic mitochondrial epigenetic mechanisms of gene regulation. However, it is still not clear how these modifications functionally affect mtDNA even though it is very likely that they influence mitochondrial gene expression and biogenesis. Shock et al. reported not only the presence of $5 \mathrm{mC}$ and $5 \mathrm{hmC}$ in mammalian mtDNA, but also a mitochondrial DNMT1 that binds to the mtDNA and regulates the expression of particular mitochondrial genes (Shock et al., 2011). Interestingly, we observed a decrease in DNMT1 mRNA levels after DOX treatment, which was similar to previous reports (Krushkal et al., 2016; Yokochi and Robertson, 2004). This DNMT1 down-regulation was most pronounced at day 0 , right after the exposure to DOX, and resolved over time. We hypothesize that DNMT1 could be involved in the regulation of mitochondrial gene expression. Actually, although not mitochondrial specific, the total $5 \mathrm{mC}$ signal obtained from immunocytochemistry analysis was lower in DOXtreated cells compared to controls. Similar results have been previously reported, in which chronic DOX exposure was followed by a global decrease of DNA methylation in cardiac tissue. (Nordgren et al., 2017; Ferreira et al., 2017). We speculate a possible reduction in the levels of mtDNA methylation caused by the lack of DNMT1, which could result in upregulation of some mitochondrial genes and maintenance of mitochondrial functions. In fact, hypomethylation of mtDNA was already suggested as a cause for the increased expression of mtDNA-encoded genes (Yamazaki et al., 2016). More recently, and strengthening our hypothesis, a downregulation in the expression of DNMT1 accompanied by mtDNA hypomethylation was observed under conditions of oxidative stress (Saini et al., 2017). However, it is worth mentioning that our study has some limitations that have been considered for data analyses, one being the failure to confirm mtDNA methylation. Our immunocytochemistry experiments revealed some $5 \mathrm{mC}$-positive signal in the cytoplasm of H9c2 cells, which may suggest mitochondrial staining, although this needs to be explored in further detail.

Based on the transcriptional and metabolic alterations observed in DOX-treated cells, we proposed that pre-conditioning H9c2 cells could increase resistance to a second, more severe exposure. An adaptive response to DOX has previously been shown in non-cancer cells (Anuszewska and Koziorowska, 1999), although the underlying mechanisms were not clarified. More recently, a study reported that the pretreatment with low-dose radiation was able to attenuate DOX-induced cardiotoxicity (Jiang et al., 2018). Here again, the molecular consequences of the stimulation with low-dose radiation were not totally clear, but the authors proposed that the radiation could lead to a small increase of ROS that promote the upregulation of antioxidant defenses. In the present study we exposed the pre-conditioned cells to a further $24 \mathrm{~h}$ incubation with either DOX $(0.2,0.5$ and $1 \mu \mathrm{M})$ or iodoacetate $(2 \mu \mathrm{M})$, known to irreversibly inhibit the glycolytic enzyme GAPDH. H9c2 cells previously incubated with DOX were significantly more resistant to the second treatment, demonstrated by a lesser decrease in cell mass and metabolic viability. Supporting the role of mitochondria on the cellular adaptation, the oxygen consumption rate results showed an improvement of mitochondrial functioning with the pre-treatment with DOX. This illustrates a paradoxical beneficial effect of DOX pre-exposure and supports the hypothesis that the capability of proliferating cardiac cells to adapt after DOX exposure can be an advantage to further stresses. However, our data does not provide direct evidence whether the adaptation is a result of epigenetic regulation, protective mechanisms including ROS-induced signaling pathways and pro-survival signaling or, more likely, a combination of multiple factors. Moreover, it is also possible that the first exposure could initially select the more resilient cells that later proliferate and are better able to withstand DOX-induced mitochondrial toxicity.

In conclusion, we demonstrated that exposure of $\mathrm{H} 9 \mathrm{c} 2$ cells to nanomolar concentrations of DOX increases the cellular resistance against a subsequent and more stressful dose through a process of mitochondrial adaptation, possibly epigenetic-linked (Boettcher et al., 2010; Ramachandran et al., 2016) (Fig. 7). This strategy could be particularly important for cardiac protection in patients with childhood cancers, considerably improving the DOX-induced cardiomyopathy while maintaining the anticancer treatment effectiveness.

\section{Disclosure}

The authors state that they have no conflicts of interest. The funding agencies had no role in the decision to publish or in the contents of the manuscript. 


\section{Funding}

This work was supported by Foundation for Science and Technology [grant number PTDC/DTP-FTO/1180/2012, SFRH/BD/52429/2013 to LLF, and SFRH/BPD/101169/2014 to TC-O]; European Regional Development Fund/Operational Programme for Competitiveness Factors [POCI-01-0145-FEDER-007440, POCI-01-0145-FEDER-029297 and CENTRO- 07-ST24-FEDER-002008].

\section{Appendix A. Supplementary data}

Supplementary data to this article can be found online at https:// doi.org/10.1016/j.fct.2018.12.017.

\section{Transparency document}

Transparency document related to this article can be found online at https://doi.org/10.1016/j.fct.2018.12.017.

\section{References}

Abhyankar, A., Park, H.B., Tonolo, G., Luthman, H., 2009. Comparative sequence analysis of the non-protein-coding mitochondrial DNA of inbred rat strains. PLoS One 4, e8148.

Anuszewska, E.L., Koziorowska, J.H., 1999. Capability of adriamycin and busulfan to induce adaptive response in vitro. Arch. Immunol. Ther. Exp. 47, 51-54.

Ascensao, A., Lumini-Oliveira, J., Machado, N.G., Ferreira, R.M., Goncalves, I.O. Moreira, A.C., Marques, F., Sardao, V.A., Oliveira, P.J., Magalhaes, J., 2011. Acute exercise protects against calcium-induced cardiac mitochondrial permeability transition pore opening in doxorubicin-treated rats. Clin. Sci. (London, England: 1979) 120, 37-49.

Bellizzi, D., D'Aquila, P., Scafone, T., Giordano, M., Riso, V., Riccio, A., Passarino, G., 2013. The control region of mitochondrial DNA shows an unusual CpG and non-CpG methylation pattern. DNA Res.: Int. J. Rapid Publ. Rep. Genes and Genomes 20, 537-547.

Berthiaume, J.M., Wallace, K.B., 2007a. Adriamycin-induced oxidative mitochondrial cardiotoxicity. Cell Biol. Toxicol. 23, 15-25.

Berthiaume, J.M., Wallace, K.B., 2007b. Persistent alterations to the gene expression profile of the heart subsequent to chronic Doxorubicin treatment. Cardiovasc. Toxicol. 7, 178-191.

Boettcher, M., Kischkel, F., Hoheisel, J.D., 2010. High-definition DNA methylation profiles from breast and ovarian carcinoma cell lines with differing doxorubicin resistance. PLoS One 5, e11002.

Bonadonna, G., Monfardini, S., De Lena, M., Fossati-Bellani, F., 1969. Clinical evaluation of adriamycin, a new antitumour antibiotic. Br. Med. J. 3, 503-506.

Bonadonna, G., Monfardini, S., De Lena, M., Fossati-Bellani, F., Beretta, G., 1970. Phase I and preliminary phase II evaluation of adriamycin (NSC 123127). Cancer Res. 30 2572-2582

Brand, M.D., Nicholls, D.G., 2011. Assessing mitochondrial dysfunction in cells. Biochem. J. 435, 297-312.

Capranico, G., Tinelli, S., Austin, C.A., Fisher, M.L., Zunino, F., 1992. Different patterns of gene expression of topoisomerase II isoforms in differentiated tissues during murine development. Biochim. Biophys. Acta 1132, 43-48.

Carvalho, R.A., Sousa, R.P., Cadete, V.J., Lopaschuk, G.D., Palmeira, C.M., Bjork, J.A., Wallace, K.B., 2010. Metabolic remodeling associated with subchronic doxorubicin cardiomyopathy. Toxicology 270, 92-98.

Coldwell, K.E., Cutts, S.M., Ognibene, T.J., Henderson, P.T., Phillips, D.R., 2008. Detection of Adriamycin-DNA adducts by accelerator mass spectrometry at clinically relevant Adriamycin concentrations. Nucleic Acids Res. 36, e100.

De Angelis, A., Piegari, E., Cappetta, D., Marino, L., Filippelli, A., Berrino, L., FerreiraMartins, J., Zheng, H., Hosoda, T., Rota, M., Urbanek, K., Kajstura, J., Leri, A., Rossi, F., Anversa, P., 2010. Anthracycline cardiomyopathy is mediated by depletion of the cardiac stem cell pool and is rescued by restoration of progenitor cell function. Circulation 121, 276-292.

Desai, V.G., Herman, E.H., Moland, C.L., Branham, W.S., Lewis, S.M., Davis, K.J., George, N.I., Lee, T., Kerr, S., Fuscoe, J.C., 2013. Development of doxorubicin-induced chronic cardiotoxicity in the B6C3F1 mouse model. Toxicol. Appl. Pharmacol. 266, 109-121.

Dimauro, I., Pearson, T., Caporossi, D., Jackson, M.J., 2012. A simple protocol for the subcellular fractionation of skeletal muscle cells and tissue. BMC Res. Notes 5, 513 .

Doroshow, J.H., Davies, K.J., 1986. Redox cycling of anthracyclines by cardiac mitochondria. II. Formation of superoxide anion, hydrogen peroxide, and hydroxyl radical. J. Biol. Chem. 261, 3068-3074.

Eom, Y.W., Kim, M.A., Park, S.S., Goo, M.J., Kwon, H.J., Sohn, S., Kim, W.H., Yoon, G., Choi, K.S., 2005. Two distinct modes of cell death induced by doxorubicin: apoptosis and cell death through mitotic catastrophe accompanied by senescence-like phenotype. Oncogene 24, 4765-4777.
Ferreira, A., Cunha-Oliveira, T., Simoes, R.F., Carvalho, F.S., Burgeiro, A., Nordgren, K., Wallace, K.B., Oliveira, P.J., 2017. Altered mitochondrial epigenetics associated with subchronic doxorubicin cardiotoxicity. Toxicology 390, 63-73.

Garner, E., Raj, K., 2008. Protective mechanisms of p53-p21-pRb proteins against DNA damage-induced cell death. Cell Cycle 7, 277-282.

Goorin, A.M., Chauvenet, A.R., Perez-Atayde, A.R., Cruz, J., McKone, R., Lipshultz, S.E., 1990. Initial congestive heart failure, six to ten years after doxorubicin chemotherapy for childhood cancer. J. Pediatr. 116, 144-147.

Greene, R.F., Collins, J.M., Jenkins, J.F., Speyer, J.L., Myers, C.E., 1983. Plasma pharmacokinetics of adriamycin and adriamycinol: implications for the design of in vitro experiments and treatment protocols. Cancer Res. 43, 3417-3421.

He, B., Yin, C., Gong, Y., Liu, J., Guo, H., Zhao, R., 2017. Melatonin-induced Increase of Lipid Droplets Accumulation and in Vitro Maturation in Porcine Oocytes is Mediated by Mitochondrial Quiescence.

Huang, C., Zhang, X., Ramil, J.M., Rikka, S., Kim, L., Lee, Y., Gude, N.A., Thistlethwaite, P.A., Sussman, M.A., Gottlieb, R.A., Gustafsson, A.B., 2010. Juvenile exposure to anthracyclines impairs cardiac progenitor cell function and vascularization resulting in greater susceptibility to stress-induced myocardial injury in adult mice. Circulation $121,675-683$.

Jiang, X., Hong, Y., Zhao, D., Meng, X., Zhao, L., Du, Y., Wang, Z., Zheng, Y., Cai, L., Jiang, H., 2018. Low dose radiation prevents doxorubicin-induced cardiotoxicity. Oncotarget 9, 332-345.

Kimes, B.W., Brandt, B.L., 1976. Properties of a clonal muscle cell line from rat heart. Exp. Cell Res. 98, 367-381.

Krushkal, J., Zhao, Y., Hose, C., Monks, A., Doroshow, J.H., Simon, R., 2016. Concerted changes in transcriptional regulation of genes involved in DNA methylation, demethylation, and folate-mediated one-carbon metabolism pathways in the NCI-60 cancer cell line panel in response to cancer drug treatment. Clin. Epigenet. 8, 73.

Lenco, J., Lencova-Popelova, O., Link, M., Jirkovska, A., Tambor, V., Potuckova, E., Stulik, J., Simunek, T., Sterba, M., 2015. Proteomic investigation of embryonic rat heart-derived H9c2 cell line sheds new light on the molecular phenotype of the popular cell model. Exp. Cell Res. 339, 174-186.

Lipshultz, S.E., Colan, S.D., Gelber, R.D., Perez-Atayde, A.R., Sallan, S.E., Sanders, S.P., 1991. Late cardiac effects of doxorubicin therapy for acute lymphoblastic leukemia in childhood. N. Engl. J. Med. 324, 808-815.

Lv, X., Yu, X., Wang, Y., Wang, F., Li, H., Wang, Y., Lu, D., Qi, R., Wang, H., 2012. Berberine inhibits doxorubicin-triggered cardiomyocyte apoptosis via attenuating mitochondrial dysfunction and increasing Bcl-2 expression. PLoS One 7, e47351.

Maejima, Y., Adachi, S., Ito, H., Hirao, K., Isobe, M., 2008. Induction of premature senescence in cardiomyocytes by doxorubicin as a novel mechanism of myocardial damage. Aging Cell 7, 125-136.

Merten, K.E., Jiang, Y., Feng, W., Kang, Y.J., 2006. Calcineurin activation is not necessary for Doxorubicin-induced hypertrophy in H9c2 embryonic rat cardiac cells: involvement of the phosphoinositide 3-kinase-Akt pathway. J. Pharmacol. Exp. Therapeut. 319, 934-940.

Minotti, G., Menna, P., Salvatorelli, E., Cairo, G., Gianni, L., 2004. Anthracyclines: molecular advances and pharmacologic developments in antitumor activity and cardiotoxicity. Pharmacol. Rev. 56, 185-229.

Nitiss, J.L., 2009. Targeting DNA topoisomerase II in cancer chemotherapy. Nat. Rev. Canc. 9, 338-350.

Niu, J., Azfer, A., Wang, K., Wang, X., Kolattukudy, P.E., 2009. Cardiac-targeted expression of soluble fas attenuates doxorubicin-induced cardiotoxicity in mice. J. Pharmacol. Exp. Therapeut. 328, 740-748.

Nordgren, K.K.S., Hampton, M., Wallace, K.B., 2017. Editor's highlight: the altered DNA methylome of chronic doxorubicin exposure in sprague dawley rats. Toxicol. Sci. Off. J. Soc. Toxicol. 159, 470-479.

Oliveira, P.J., Bjork, J.A., Santos, M.S., Leino, R.L., Froberg, M.K., Moreno, A.J., Wallace, K.B., 2004. Carvedilol-mediated antioxidant protection against doxorubicin-induced cardiac mitochondrial toxicity. Toxicol. Appl. Pharmacol. 200, 159-168.

Oyama, K., Takahashi, K., Sakurai, K., 2011. Hydrogen peroxide induces cell cycle arrest in cardiomyoblast H9c2 cells, which is related to hypertrophy. Biol. Pharm. Bull. 34, 501-506.

Pereira, G.C., Pereira, S.P., Pereira, C.V., Lumini, J.A., Magalhaes, J., Ascensao, A., Santos, M.S., Moreno, A.J., Oliveira, P.J., 2012. Mitochondrionopathy phenotype in doxorubicin-treated Wistar rats depends on treatment protocol and is cardiac-specific. PLoS One 7, e38867.

Pillai, V.B., Bindu, S., Sharp, W., Fang, Y.H., Kim, G., Gupta, M., Samant, S., Gupta, M.P., 2016. Sirt3 protects mitochondrial DNA damage and blocks the development of doxorubicin-induced cardiomyopathy in mice. Am. J. Physiol. Heart Circ. Physiol. 310, H962-H972.

Ramachandran, K., Speer, C., Nathanson, L., Claros, M., Singal, R., 2016. Role of DNA methylation in cabazitaxel resistance in prostate cancer. Anticancer Res. 36, 161-168.

Richard, C., Ghibu, S., Delemasure-Chalumeau, S., Guilland, J.C., Des Rosiers, C., Zeller, M., Cottin, Y., Rochette, L., Vergely, C., 2011. Oxidative stress and myocardial gene alterations associated with Doxorubicin-induced cardiotoxicity in rats persist for 2 months after treatment cessation. J. Pharmacol. Exp. Therapeut. 339, 807-814.

Saini, S.K., Mangalhara, K.C., Prakasam, G., Bamezai, R.N.K., 2017. DNA Methyltransferase1 (DNMT1) Isoform3 methylates mitochondrial genome and modulates its biology. Sci. Rep. 7, 1525.

Sardao, V.A., Oliveira, P.J., Holy, J., Oliveira, C.R., Wallace, K.B., 2009a. Doxorubicininduced mitochondrial dysfunction is secondary to nuclear p53 activation in H9c2 cardiomyoblasts. Cancer Chemother. Pharmacol. 64, 811-827. 
Sardao, V.A., Oliveira, P.J., Holy, J., Oliveira, C.R., Wallace, K.B., 2009b. Morphological alterations induced by doxorubicin on $\mathrm{H} 9 \mathrm{c} 2$ myoblasts: nuclear, mitochondrial, and cytoskeletal targets. Cell Biol. Toxicol. 25, 227-243.

Serrano, J., Palmeira, C.M., Kuehl, D.W., Wallace, K.B., 1999. Cardioselective and cumulative oxidation of mitochondrial DNA following subchronic doxorubicin administration. Biochim. Biophys. Acta 1411, 201-205.

Shock, L.S., Thakkar, P.V., Peterson, E.J., Moran, R.G., Taylor, S.M., 2011. DNA methyltransferase 1 , cytosine methylation, and cytosine hydroxymethylation in mammalian mitochondria. Proc. Natl. Acad. Sci. U.S.A. 108, 3630-3635.

Strigun, A., Wahrheit, J., Niklas, J., Heinzle, E., Noor, F., 2012. Doxorubicin increases oxidative metabolism in HL-1 cardiomyocytes as shown by 13C metabolic flux analysis. Toxicol. Sci. : Off. J. Soc. Toxicol. 125, 595-606.

Venkatakrishnan, C.D., Dunsmore, K., Wong, H., Roy, S., Sen, C.K., Wani, A., Zweier, J.L., Ilangovan, G., 2008. HSP27 regulates p53 transcriptional activity in doxorubicintreated fibroblasts and cardiac H9c2 cells: p21 upregulation and G2/M phase cell cycle arrest. Am. J. Physiol. Heart Circ. Physiol. 294, H1736-H1744.

Vichai, V., Kirtikara, K., 2006. Sulforhodamine B colorimetric assay for cytotoxicity screening. Nat. Protoc. 1, 1112-1116.

Von Hoff, D.D., Layard, M.W., Basa, P., Davis Jr., H.L., Von Hoff, A.L., Rozencweig, M., Muggia, F.M., 1979. Risk factors for doxorubicin-induced congestive heart failure. Ann. Intern. Med. 91, 710-717.

Wallace, K.B., 2007. Adriamycin-induced interference with cardiac mitochondrial calcium homeostasis. Cardiovasc. Toxicol. 7, 101-107.

Wouters, K.A., Kremer, L.C., Miller, T.L., Herman, E.H., Lipshultz, S.E., 2005. Protecting against anthracycline-induced myocardial damage: a review of the most promising strategies. Br. J. Haematol. 131, 561-578.

Yamazaki, M., Munetsuna, E., Yamada, H., Ando, Y., Mizuno, G., Murase, Y., Kondo, K., Ishikawa, H., Teradaira, R., Suzuki, K., Ohashi, K., 2016. Fructose consumption induces hypomethylation of hepatic mitochondrial DNA in rats. Life Sci. 149, 146-152.

Yang, F., Teves, S.S., Kemp, C.J., Henikoff, S., 2014. Doxorubicin, DNA torsion, and chromatin dynamics. Biochim. Biophys. Acta 1845, 84-89.

Yokochi, T., Robertson, K.D., 2004. Doxorubicin inhibits DNMT1, resulting in conditional apoptosis. Mol. Pharmacol. 66, 1415-1420.

Zhang, S., Liu, X., Bawa-Khalfe, T., Lu, L.S., Lyu, Y.L., Liu, L.F., Yeh, E.T., 2012 Identification of the molecular basis of doxorubicin-induced cardiotoxicity. Nat. Med. $18,1639-1642$.

Zhao, Y., Miriyala, S., Miao, L., Mitov, M., Schnell, D., Dhar, S.K., Cai, J., Klein, J.B., Sultana, R., Butterfield, D.A., Vore, M., Batinic-Haberle, I., Bondada, S., St Clair, D.K., 2014. Redox proteomic identification of HNE-bound mitochondrial proteins in cardiac tissues reveals a systemic effect on energy metabolism after doxorubicin treatment. Free Radic. Biol. Med. 72, 55-65.

Zhou, S., Palmeira, C.M., Wallace, K.B., 2001a. Doxorubicin-induced persistent oxidative stress to cardiac myocytes. Toxicol. Lett. 121, 151-157.

Zhou, S., Starkov, A., Froberg, M.K., Leino, R.L., Wallace, K.B., 2001b. Cumulative and irreversible cardiac mitochondrial dysfunction induced by doxorubicin. Cancer Res. 61, 771-777.

Zhu, W., Shou, W., Payne, R.M., Caldwell, R., Field, L.J., 2008. A mouse model for juvenile doxorubicin-induced cardiac dysfunction. Pediatr. Res. 64, 488-494. 